\title{
Using Short Stories to Motivate Intermediate EFL Learners in Essay Writing at Vietnam Centre Point
}

\author{
Giang Nguyen Truong ${ }^{1 *}$, Ha Nguyen Dinh $\mathrm{Nhu}^{2}$, Tuyen Tran $^{3}$ \\ ${ }^{1}$ Vietnam Centre Point - Vietnam \\ ${ }^{2,3}$ Institute of Technical Education - Vietnam
}

*Corresponding Authors: Giang Nguyen Truong, Vietnam Centre Point - Vietnam

\begin{abstract}
The study aims to investigate using short stories to motivate intermediate EFL learners in essay writing at Vietnam Centre Point. This study concerned in 45 intermediate leaners who were studying at Vietnam Centre Point, the researcher's workplace. This study adopted a sequential mixed method approach to data collection and analysis. Both quantitative and qualitative data were gathered from the questionnaire and semi-structured interviews. The findings expressed that attitudes of the learners (containing affective, behavioral and cognitive components) and factors motivating them (consisting of intrinsic and extrinsic motivation) in their essay writing through using short stories mostly had positive outcomes. In terms of attitudes, the most major impact was affective attitudes which had the highest mean score among the components while behavioral and cognitive components were considered to be less influential on the learners. Whilst, concerning motivation towards the learners, the dominant factor belonged to extrinsic motivation whereas intrinsic motivation had less effective influence. Depending on the findings of the study, recommendations for the learners, teachers, and administrators are also suggested.
\end{abstract}

Keywords: writing, short stories, motivation, attitude, English essay

\section{INTRODUCTION}

Among four main skills of English learning, writing is mostly considered to be the hardest skill. Whilst, writing is one of the productive skills, which is a special kind of communication, providing learners chances to produce their feelings, their ideas and their learned knowledge on the visual words. Even so, most of the English learners in Vietnam have experienced conventional and unsuitable teaching styles during their period time of studying, and this drives them to the demotivation of cultivating the target language and to the lack of critical thinking to write. Moreover, materials that teachers have used in the classes might be a complex matter since the learners are forced to study repeated topics and familiar ways of doing exercises in most of their time of practicing writing. It means that leaners are understandably not given enough vacancies of their critical thinking in each learning product as well as they would lack the inspiration for reading books. Additionally, the aims of learning or teaching English language are to build the learners to be competent communicators and users of this language. That path of learning and teaching should highlightthe higher values of teaching which are compassion, attitude, kindness exploited inside learners' characteristics.

Over the last few decades, abundant arguments on the profits of making any attempt to utilize effective teaching tools to motivate the learners to write effectively have been widely discussed. These tools could be poetries, dramas, novels, music, films or even stories which are parts of teaching English these days. Although each genre has its own advance in the course of study, the lately studies have shown that the association of stories in teaching English is more prominent. Ellis and Brewster (1991:1-2) gave several reasons for teachers to implement familiar stories in English classes. First of all, stories could enhance the learners' knowledge background and their experience since the stories are addressing them motivation and fun which raises the optimistic attitudes towards the target language. Furthermore, through stories, learners would have chances to develop their constancy in learning English, especially in writing. 
In general, based on the usefulness of the familiar English short stories in motivating essay writing, the following research questions were formulated:

1. What are the learners' attitudes towards using English short stories in enhancing writing essays?

2. How can short stories motivate EFL learners in essay writing?

\section{LITERATURE REVIEW}

Generally, there have been a great number of articles and research carried on the topics of using stories in teaching language. There was a research of Krashen and Terrell (1983) expressing the meaningful effect of various genres of stories towards the readers. He claimed it is believed by a lot of psychologists that most of the people (children as well) naturally have love in stories, legends and fairy tales since stories play a crucial role in the intellectually imaginative life of the human. The stories also evolve the fantasy world and provide people answers to the questions which are not able to be told in real life. Moreover, the stories are greatly meaningful and effectual instruments of people's society. Whilst, myths, and legends provide the children basic items which teach them to create their original concepts and purposes of the world and of the paragons which they might accompany. Slatterly and Willis (2001) had a research that it is highly useful to implement stories in the learning of language learners since they would receive actively and naturally. Hence, teachers should apply some sufficient activities related to stories to assist the learners' acquisition.

On an article on approaches to ESL/EFL writing conducted by Hasan and Akhand (2010), it was examined that activities implemented in teaching essay showed that the teachers did not provide enough motivation as it had been expected (70\% of the teachers gave the translation of the hard words into the first language). Furthermore, they discovered that the teachers did not have the pleasure of teaching essay writing due to the lack of language competence of the learners in the target language. The researchers also emphasized that the learners were poor at writing skills and found that they had the demotivation from the writing teachers. The teachers were naturally statistical, and they could not place the fields at which the learners actually expected to develop.There were a number of scholars such as Graham and Harris (1989), Bruning and Horn (2000), and Kotula, Tivnan, and Aguilar (2014) who examined that there was optimistic connection of the process of writing and the learners and the learners' attitudes in writing. Similarly, McKenna, Kear, \& Ellsworth (1995) revealed their study that leaners who embrace positive attitudes in writing have much higher tendency of effectively writing than those who possess negative ones. In a specific study, Leable (2014; p.3) showed the observation that attitude of a child could play a main role in the process of writing and could also impact his motivation as well as competency of writing, and it would have an effect on writing competence through its influence on cognitive component. Furthermore, Hashemian and Heidari (2013) informed in their study that attitude of the learners towards writing in English language is one of the primary factors which might affect second language writing. That could be interpreted that one of the most efficient ways to enhance writing skills of EFL learners and their feasible positive attitudes towards writing is to cautiously extinguish their negative thinking.In addition, Ansarimoghaddam and Tan (2014) had comparison of how their students in university thought of writing in their L1 versus English to explore a correlation between optimistic attitudes and preference in English writing. The results of the study depicted that participants who liked writing in English more than writing in their native language had more frequency of using English as performing tasks of writing. Likewise, the study of Merisuo-Storm (2007) demonstrated the correlational relation between attitudes, developing of literacy, and English proficiency. The participants who joined in his study, in a bilingual FinnishEnglish program, expressed more positive attitudes towards learning language, had greater rates of literacy, and were more skillful in using English than the control groups.

Though there have been numerous studies conducted to research the use of short stories to enhance learners' writing, studies about learners' attitudes and motivation towards using short stories in writing essays are still scarce. That was why the researcher was interested in conducting this study as an effort to fill in the gap. This study aimed to investigate learners' attitudes towards using short stories in essay writing and factors motivating EFL learners in essay writing through short stories. 


\section{METHODOLOGY}

\subsection{Research setting and participants}

This study was implemented at two campuses of Vietnam Centre Point, in Ho Chi Minh City. It was established in 2000 and is a Center where learners want to acquire knowledge of English for studying abroad, English for communication, IELTS, TOEIC, SAT, and so on. The learners of the Center mostly are good students from famous schools in Ho Chi Minh City, and many of them have excellently had chances to study abroad at well-known Universities or High Schools in European Countries, America, Singapore, etc. Especially, plenty of learners at this Center obtained high scores in IELTS, SAT, or scholarships of ASTAR, NUS, NTU in Singapore. Furthermore, the Center has a great number of teachers who received post-graduate degrees (Master, Doctor), and some of them are teaching at Universities and have had a great deal of experience of learning, working abroad. The participants of this study were 45 EFL learners in 3 to 4 different classes at the level of Intermediate in Vietnam Centre Point. The learners at the center are mostly high school students in Ho Chi Minh City, though there were also a few University students.

Table1. Demographic information of the participants

\begin{tabular}{|c|c|c|c|}
\hline \multirow[t]{2}{*}{ No } & \multirow[t]{2}{*}{ ontent } & \multicolumn{2}{|l|}{$\mathrm{N}=45$} \\
\hline & & FREQUENCY & PERCENT \\
\hline \multirow[t]{2}{*}{ Gender } & Male & 20 & 44.4 \\
\hline & Female & 25 & 55.6 \\
\hline \multirow[t]{3}{*}{ Age } & $<13$ & 2 & 4.4 \\
\hline & $13-18$ & 28 & 62.3 \\
\hline & $>18$ & 15 & 33.3 \\
\hline \multirow{3}{*}{$\begin{array}{l}\text { Years of studying } \\
\text { English }\end{array}$} & $<3$ years & 7 & 15.6 \\
\hline & 3-6 years & 23 & 51.1 \\
\hline & $>6$ years & 15 & 33.3 \\
\hline \multirow{3}{*}{$\begin{array}{l}\text { Hours per week } \\
\text { spent on writing at } \\
\text { home }\end{array}$} & $<1 \mathrm{~h}$ & 16 & 35.6 \\
\hline & $1-3 h$ & 21 & 46.6 \\
\hline & $>3 h$ & 8 & 17.8 \\
\hline
\end{tabular}

\subsection{Research Instruments}

\subsubsection{Questionnaire}

The researcher used Likert scale items and closed-ended questions for the questionnaire in this study. The good points of Likert scale items are that the answers are indicated in various intensities in order that participants could give their answers quickly and effectively. Besides, the five-point scale was used in this study since it is considered to be less confusing and to raise the rate of responses, and it is more reliable for surveys (Jenkins \& Taber, 1977). Furthermore, it supported the research to collect and synthesize the data easily. With closed-ended questions, the researcher implemented it as Oppenheim (2001) reveals some positive sides as follows: saving time and cost, processing easily and being useful to test hypothesis. The items in the questionnaire in this paper was in the form of Likert scale items ranked on 5 selections containing "strongly disagree", "disagree", "neutral", "agree" and "strongly agree".

\subsubsection{Interview}

Regarding to the semi-structured interview, there were eight open-ended questions in the interview of this study. Questions from (1) to (4) aimed to investigate the attitudes of the learners towards using short stories to enhance their essay writing, while questions from (5) to (8) had the purposes of exploring the factors motivating EFL learners in essay writing through short stories.

\subsection{Data Analysis}

The researcher used quantitative date descended from the questionnaires for learners to analyze by employing SPSS, and it was sure to examine the data of the questionnaires by using descriptive statistics. Meanwhile, qualitative data was derived from the information from the semi-structured interviews of the participants. The data from them particularly devoted deeper analysis for this study, and also provided connections between the views of the learners and the short stories about the motivation of writing essays. 


\section{FINDINGS AND DISCUSSION}

\subsection{Findings}

\subsubsection{Learner's attitudes towards using English short stories in enhancing writing essays}

It is depicted in the table 2 that the learners revealed highly positive attitudes via English short stories in three elements of attitudes: affective, behavioral, and cognitive. Despite the high means, the responses of the learners to each of the element were not identical. Regarding to affective component, their attitudes experienced the highest proportion of mean $(\mathrm{M}=3.77 ; \mathrm{SD}=.77)$. The second rank of attitudes belonged to cognitive attitude $(\mathrm{M}=3.61 ; \mathrm{SD}=.82)$. Among three components of attitudes, behavioral attitude approached the third position $(\mathrm{M}=3.57$; $\mathrm{SD}=.85)$, which was lower than two other components.

Table2. Learner's attitudes towards using English short stories in enhancing writing essays

\begin{tabular}{|l|l|l|l|}
\hline \multirow{2}{*}{ No. } & \multirow{2}{*}{ Attitudes } & $\mathbf{N}=\mathbf{4 5}$ & SD \\
\cline { 3 - 4 } & & $\mathbf{M}$ & .77 \\
\hline 1 & Affective attitudes & 3.77 & .85 \\
\hline 2 & Behavioral attitudes & 3.57 & .82 \\
\hline 3 & Cognitive attitudes & 3.61 & $\mathbf{. 8 1}$ \\
\hline Total & $\mathbf{3 . 6 5}$ & \\
\hline
\end{tabular}

Note: M: mean; SD: Standard deviation

These data are analyzed and reported descriptively as follows:

\section{Affective attitudes}

The affective attitudes of the learners towards using English short stories in enhancing writing essays were evaluated by 6 items. In the Table 3, most of the affective attitudes of the learners via using English short stories to enhance writing essays were positive with the high mean ( $M=3.77 ; \mathrm{SD}=.77)$. The mean score had the range from 3.51 to 3.87, which indicates that using English short stories affected leaners' writing optimistically.

Table3. Learners' affective attitudes towards using English short stories for essay writing

\begin{tabular}{|c|c|c|c|}
\hline \multirow{2}{*}{ No. } & \multirow{2}{*}{ Affective Attitudes } & \multicolumn{2}{|c|}{$\mathrm{N}=45$} \\
\hline & & $\mathbf{M}$ & SD \\
\hline 1 & $\begin{array}{l}\text { I am interested in using short stories to practice } \\
\text { essay writing }\end{array}$ & 3.73 & .688 \\
\hline 2 & $\begin{array}{l}\text { After using short stories, I feel more confident } \\
\text { when I write essays }\end{array}$ & 3.51 & .787 \\
\hline 3 & $\begin{array}{l}\text { I find that I learn a lot of valuable lessons from } \\
\text { using short stories to use for essay writing }\end{array}$ & 3.82 & .614 \\
\hline 4 & $\begin{array}{l}\text { I find essay writing more enjoyable after reading } \\
\text { short stories }\end{array}$ & 3.84 & .824 \\
\hline 5 & $\begin{array}{l}\text { I feel using short stories helps me write more } \\
\text { effectively }\end{array}$ & 3.87 & .894 \\
\hline 6 & $\begin{array}{l}\text { I feel that I can be a good writer if I read short } \\
\text { stories more regularly }\end{array}$ & 3.84 & .796 \\
\hline \multicolumn{2}{|c|}{ Total } & 3.77 & .77 \\
\hline
\end{tabular}

Note: : mean; SD: Standard deviation

As can be seen from the above table, the highest mean belongs to the item 5 ( $M=3.87 ; \mathrm{SD}=.894$ ), which shows that the learners mostly agreed to feel using short stories helps them write more effectively. Thus, the majority of the learners found that essay writing was much more enjoyable after reading short stories (item 4; $\mathrm{M}=3.84 ; \mathrm{SD}=.824$ ), and felt that they could be better writers if they read short stories more regularly (item 6; $\mathrm{M}=3.84 ; \mathrm{SD}=.796$ ). Thanks to the English short stories, most learners found that they learnt a lot of lessons to use for writing essays (item 3; M=3.82; SD=.614). Furthermore, they agreed that they were highly interested in using short stories to practice essay writing (item 1; $\mathrm{M}=3.73 ; \mathrm{SD}=.688$ ). The learners also admitted that they felt more confident in writing essays after they read short stories (item 2, M=3.51; $\mathrm{SD}=787$ ). 
To thoroughly illustrate the affective attitudes of the learners in using short stories in writing essays, the qualitative date collected from the interview was used. There were some bright responses from the interview as follows:

"I think I can write more effectively since short stories contains the topics in my writing, and helps me have clear ideas for my writing. Besides, it helps me memorize my own experience to write more easily. Furthermore, the texts provide me more vocabulary for me to apply in my writing effectively." (S2)

"I can write more effectively because short stories have lots of useful vocabulary for me to learn. Likewise, English short stories have many good structures, coherent writing styles, and cohesive devices which help me write better." (S4)

\section{Behavioral attitudes}

The table 4 shows the behavioral attitudes of the learners in using short stories for the purpose of writing essays, and it was also assessed by 6 items. In the table, the mean score of the behavioral attitudes was rather high $(\mathrm{M}=3.57 ; \mathrm{SD}=.85)$, which means that most of the learners had the positive behavioral attitudes towards using short stories in enhancing writing skills. The range of mean scores ranged from 3.56 to 3.76 (except for item 12 with the mean score at 3.31).

Table4. Learners' behavioral attitudes towards using English short stories for essay writing

\begin{tabular}{|c|c|c|c|}
\hline \multirow{2}{*}{ No. } & \multirow{2}{*}{ Behavioral Attitudes } & \multicolumn{2}{|c|}{$\mathrm{N}=45$} \\
\hline & & $\mathbf{M}$ & SD \\
\hline 7 & $\begin{array}{l}\text { I always take notes of useful words, phrases to use } \\
\text { in my writing when I read short stories }\end{array}$ & 3.56 & .785 \\
\hline 8 & I spend more time on practicing essay writing & 3.62 & .860 \\
\hline 9 & $\begin{array}{l}\text { I have higher concentration when reading short } \\
\text { stories to upgrade my writing skills }\end{array}$ & 3.76 & .830 \\
\hline 10 & $\begin{array}{l}\text { I practice writing more actively after using short } \\
\text { stories in my class. }\end{array}$ & 3.60 & .939 \\
\hline 11 & $\begin{array}{l}\text { I expect to have more chances to use short stories in } \\
\text { my writing classes }\end{array}$ & 3.56 & .841 \\
\hline 12 & $\begin{array}{l}\text { I find more short stories to read to enhance my } \\
\text { writing skills }\end{array}$ & 3.31 & .874 \\
\hline \multicolumn{2}{|c|}{ Total } & 3.57 & .85 \\
\hline
\end{tabular}

Note: M: mean; SD: Standard deviation

According to the table 4, with the highest mean score, most of the participants accepted that they higher concentration when reading short stories to upgrade their writing skills (item 9; $M=3.76$; $\mathrm{SD}=.830$ ). The second rank of the mean score belongs to item 8 , which shows that the learners spent more time on practicing essay $(\mathrm{M}=3.62 ; \mathrm{SD}=.860)$. With the lower mean score, item 10 expressed that most of the participants practiced writing more actively after using short stories in their classes. $(\mathrm{M}=2.60 ; \mathrm{SD}=.939)$. Moreover, with the majority of agreement, the learners revealed that they always took notes of useful words, phrases to use in their writing when they read short stories (item 7; $\mathrm{M}=3.56$; $\mathrm{SD}=.785$ ). Likewise, with the same mean score, most of the learners expected to have more chances to use short stories in their writing classes (item 11; M=3.56; $\mathrm{SD}=.841$ ). With the lowest mean score in this domain of attitudes, it is admitted that the learners mostly had neutral opinion of finding more interesting short stories to read to enhance their writing skills (item; $M=3.31 ; \mathrm{SD}=.874$ ).

Aligning with the quantitative data collected from the questionnaire, qualitative data was also utilized to support the optimistic behavioral attitudes of the learners. From the interview, the learners had some positive comments about the concentration during using short stories in their writing classes:

"Reading short stories for writing essays requires higher concentration than usual reading because I have to read slowly and pay closer attention to every small details of the story which would be missed easily if not careful." (S1)

Another optimistic view point about the concentration when using short stories was given as that:

"Reading short stories frequently helps me upgrade my concentration, and patience, which helps my writing a lot because I have to focus on memorizing vocabulary and ideas." (S5) 


\section{Cognitive attitudes}

This kind of attitudes expresses the belief and the notion of the learners, and the table 5 provides information about cognitive attitudes towards using English short stories in essay writing. As can be seen, the mean score of this component of attitudes was rather high $(\mathrm{M}=3.61 ; \mathrm{SD}=.82)$, which shows the positive cognitive attitudes of the learner in using short stories for their wring skills.

Table5. Learners' cognitive attitudes towards using English short stories for essay writing

\begin{tabular}{|c|c|c|c|}
\hline \multirow{2}{*}{ No. } & \multirow{2}{*}{ Cognitive Attitudes } & \multicolumn{2}{|c|}{$\mathrm{N}=45$} \\
\hline & & $\mathbf{M}$ & SD \\
\hline 13 & $\begin{array}{l}\text { English short stories assist me to receive more } \\
\text { useful sentence structures in writing. }\end{array}$ & 3.60 & .751 \\
\hline 14 & $\begin{array}{l}\text { I can deeply comprehend the ideas from the topics } \\
\text { after reading short stories. }\end{array}$ & 3.53 & .757 \\
\hline 15 & $\begin{array}{l}\text { I can collect many useful words or word phrases } \\
\text { from the short stories for my writing. }\end{array}$ & 3.80 & .842 \\
\hline 16 & $\begin{array}{l}\text { Short stories provide me background knowledge } \\
\text { and ideas for my writing. }\end{array}$ & 3.60 & .863 \\
\hline 17 & $\begin{array}{l}\text { The lessons from the short stories help me have } \\
\text { more critical thinking in writing. }\end{array}$ & 3.69 & .763 \\
\hline 18 & $\begin{array}{l}\text { I can present my ideas more clearly after reading } \\
\text { the given short stories. }\end{array}$ & 3.47 & .919 \\
\hline \multicolumn{2}{|c|}{ Total } & 3.61 & .82 \\
\hline
\end{tabular}

Note: M: mean; SD: Standard deviation

To examine more details, in the table 5, the highest rank of mean score in this domain belongs to item 15 ( $\mathrm{M}=3.80 ; \mathrm{SD}=.842)$, in which the participants agreed that they could collect many useful words or word phrases from the short stories for their writing. Equally important, most participants had their agreement that the lessons from the short stories helped them have more critical thinking in writing (item 17; $\mathrm{M}=3.69 ; \mathrm{SD}=.763$ ). In addition, they concurred that English short stories assisted them to receive more useful sentence structures in writing (item 13; $\mathrm{M}=3.60 ; \mathrm{SD}=.751$ ), and Short stories provided them background knowledge and ideas for their writing (item $16 ; \mathrm{M}=3.60 ; \mathrm{SD}=.863$ ). They also admitted that they could deeply comprehend the ideas from the topics after reading short stories (item 14; $\mathrm{M}=3.53 ; \mathrm{SD}=.757$ ). The last rank of mean score in this table is in item 18; However, most of the participant still agreed that they could present their ideas more clearly after reading the given short stories (item 18; $\mathrm{M}=3.47 ; \mathrm{SD}=.919$ ).

To have further analysis of the qualitative data in cognitive attitudes of the learners, most of the interviewees had high positive comments about effectively collecting new words and phrases from short stories that:

"I do usually collect many useful words and phrases given in short stories and I prefer using them for my essays due to my purpose for reading stories." (S3)

"I collect a lot of new words and phrases from the short stories. There are many notable adjectives, verbs and nouns in those stories, and they are extremely useful in my writing." (S5)

Beside those, the participants' viewpoints about using short stories to develop their critical thinking in writing also had good tendency as follow:

"The lessons in short stories are helpful for my critical thinking. It is because there are a lot of topics which have many ideas I have never experience." (S2)

"I think I can upgrade my critical thinking from the short stories. It is because they usually contain familiar contents and messages to the readers, and I can imagine the lessons as the clues for my writing." (S4)

\subsubsection{Factors Motivating EFL Learners in Essay Writing Through Short Stories}

The table6 informs factors which motivated learners in using short stories in writing essays. It could be clearly seen that the total mean of the motivation was positive $(\mathrm{M}=3.69 ; \mathrm{SD}=.80)$, which means that most of the learners had high motivation in utilizing short stories for their writing. 
Table6. Factors motivating EFL learners in essay writing through short stories

\begin{tabular}{|l|l|l|l|}
\hline \multirow{2}{*}{ No. } & \multirow{2}{*}{ Motivation } & $\mathbf{N}=\mathbf{4 5}$ & SD \\
\cline { 3 - 4 } & & $\mathbf{M}$ & .84 \\
\hline 1 & Intrinsic motivation & 3.62 & .75 \\
\hline 2 & Extrinsic motivation & 3.76 & $\mathbf{. 8 0}$ \\
\hline Total & $\mathbf{3 . 6 9}$ & \\
\hline
\end{tabular}

Note: M: mean; SD: Standard deviation

In the above table, it is described that the learners possessed quite strong motivation (both intrinsic motivation and extrinsic motivation) in using short stories in essay writing. The highest mean score was seen in extrinsic motivation $(\mathrm{M}=3.76 ; \mathrm{SD}=.75)$. Meanwhile, intrinsic motivation experienced lower mean score $(\mathrm{M}=3.62 ; \mathrm{SD}=.84)$, which means that the learners beneficially acquired more extrinsic motivation than intrinsic motivation in using short stories for their essay writing.

These data of intrinsic and extrinsic motivation are analyzed and reported descriptively as follows:

\section{Intrinsic motivation}

Intrinsic motivation of the learners in essay writing through short stories was evaluated by 6 items, which had the range of mean scores from 3.42 to 3.82. This means that most of the learners received positive tendency of intrinsic motivation.

Table7. Intrinsic motivation of EFL learners in essay writing through short stories

\begin{tabular}{|c|c|c|c|}
\hline \multirow{2}{*}{ No. } & \multirow{2}{*}{ Intrinsic Motivation } & \multicolumn{2}{|c|}{$\mathrm{N}=45$} \\
\hline & & $\mathbf{M}$ & SD \\
\hline 19 & $\begin{array}{l}\text { Reading short stories helps me to search and collect } \\
\text { more new ideas autonomically }\end{array}$ & 3.67 & .826 \\
\hline 20 & $\begin{array}{l}\text { I have more expectation of upgrading writing level } \\
\text { after reading short stories }\end{array}$ & 3.62 & .886 \\
\hline 21 & I have the enjoyment of the storytelling & 3.82 & .716 \\
\hline 22 & $\begin{array}{l}\text { I could relieve the stress as using short stories for } \\
\text { essay writing }\end{array}$ & 3.42 & .917 \\
\hline 23 & I like experiencing new things from the short stories & 3.58 & .866 \\
\hline 24 & I have more choices to develop my writing skills & 3.58 & .839 \\
\hline \multicolumn{2}{|c|}{ Total } & 3.62 & .84 \\
\hline
\end{tabular}

Note: M: mean; SD: Standard deviation

According to the table 7, the highest mean score belongs to the enjoyment of the storytelling that the learners had (item 21; $\mathrm{M}=3.82 ; \mathrm{SD}=.716$ ). The second mean score of intrinsic motivation was provided in item 19, in which the learners mostly agreed that reading short stories helped them to search and collect more new ideas autonomically $(\mathrm{M}=3.67 ; \mathrm{SD}=.826)$. Furthermore, they admitted that they had more expectation of upgrading writing level after reading short stories (item 20; $\mathrm{M}=3.62 ; \mathrm{SD}=.886$ ). Other agreements of the learners were that they liked experiencing new things from the short stories (item 23; $\mathrm{M}=3.58 ; \mathrm{SD}=.866$ ), and they had more choices to develop my writing skills (item 24; $\mathrm{M}=3.58 ; \mathrm{SD}=.84$ ). Though being in the lowest rank of mean score in the table, item 22 showed that most of the learners agreed they could relieve the stress as using short stories for essay writing $(\mathrm{M}=3.42 ; \mathrm{SD}=.917)$.

Concerning the data collected from the interview, most of the participant revealed their enjoyment as using short stories in their writing classes as follows:

"I feel rather relaxed and comfortable in using short stories for my writing in the class. It is because I can forget the stress of writing and focus on the story-line, and the story is very exciting." (S4)

"Using short stories help me to experience new things which normal classes cannot do, so I feel very relaxed and comfortable in my writing class." (S5)

Specially, the usefulness of the short stories was confirmed by the participants not only in their writing classes but also in their real life through some positive comments:

"I find that practicing in writing, short stories also help me develop my lifestyle or build better characteristics in my heart through the valuable lessons of them." (S2) 
"The contents, lessons and experience in the given short stories surely not only help me enhance my writing skills but also provide me the real lessons." (S5)

\section{Extrinsic motivation}

Data displayed in table 8 expresses factors which motivated the learners extrinsically in using short stories for their essay writing. Also, it was evaluated by 6 items which had the mean score ranged from 3.31 to 4.07 .

Table8. Extrinsic motivation of EFL learners in essay writing through short stories

\begin{tabular}{|c|c|c|c|}
\hline \multirow{2}{*}{ No. } & \multirow{2}{*}{ Extrinsic Motivation } & \multicolumn{2}{|c|}{$\mathrm{N}=45$} \\
\hline & & $\mathbf{M}$ & SD \\
\hline 25 & $\begin{array}{l}\text { I could get higher score/ better results in writing } \\
\text { essays after using short stories }\end{array}$ & 3.51 & .727 \\
\hline 26 & I could gain valuable skills for writing essays & 3.64 & .773 \\
\hline 27 & $\begin{array}{l}\text { I like the environment of the class when using short } \\
\text { stories in essay writing }\end{array}$ & 4.04 & .673 \\
\hline 28 & $\begin{array}{l}\text { Teacher helps me feel more confident in } \\
\text { interacting/ sharing ideas of the short stories }\end{array}$ & 3.96 & .706 \\
\hline 29 & I could decrease the number of mistakes in writing & 4.07 & .688 \\
\hline 30 & $\begin{array}{l}\text { The background knowledge from the short stories } \\
\text { could be more useful to me not only in writing } \\
\text { essays }\end{array}$ & 3.31 & .900 \\
\hline \multicolumn{2}{|c|}{ Total } & 3.76 & .75 \\
\hline
\end{tabular}

Note: M: mean; SD: Standard deviation

As being depicted in the table, among 6 items in extrinsic motivation, the highest mean score of item 29 informs that most of the learners agreed they could decrease the number of mistakes in writing $(\mathrm{M}=4.07 ; \mathrm{SD}=.688)$. Additionally, the majority of the learners experienced they liked the environment of the class when using short stories in essay writing (item 27; M=4.04; SD=.673). They also had a high level of agreement that teacher helped them feel more confident in interacting and sharing ideas of the short stories (item 28; $\mathrm{M}=3.96 ; \mathrm{SD}=.706$ ). Furthermore, the learners highly admitted that they could gain valuable skills for writing essays (item 26; $M=3.64 ; \mathrm{SD}=.773$ ), and get better results in writing essays after using short stories (item $25 ; \mathrm{M}=3.51 ; \mathrm{SD}=.727$ ). Regarding to the lowest rank of mean score, item 30 reveals that most of the leaners had neutral idea that the background knowledge from the short stories could be more useful to them not only in writing essays ( $M=3.31 ; \mathrm{SD}=.900)$.

With respect to the qualitative, the collected findings from the interview revealed that the mistakes in writing of the learners had the tendency of decreasing thank to using the short stories, and they had some optimistic opinions as follows:

"I can decrease my mistakes, but it is not considerable due to the number of stories I have read. It might be too low and I have not met my mistakes so much that I could recognize that I need to fix that mistake. But it does help me to fix my word use and also writing style." (S3)

"The mistakes in word using, grammar and writing style are decreasing after I read short stories. It is because the short stories are reliable models for me to learn and contrast my writing, and I can recognize my common mistakes in writing." (S5)

As previously mentioned, the environment in the writing classes when using short stories mostly had positive tendency towards the participants as their comments that:

"I like the atmosphere of my class during reading short stories, in which everyone read short stories quietly and I had a chance of focusing on comprehend them and brainstorming my ideas." (S2)

"The best factor helping me motivated in using short stories in my writing class was my teacher. He fascinatingly introduced the general content of the stories." (S5)

\subsection{Discussion}

\subsubsection{Learner's Attitudes towards Using English Short Stories in Enhancing Writing Essays}

In the field of attitudes towards using English short stories in essay writing, the results showed that the participants embraced highly positive attitudes, and there are three components of attitudes in this 
paper, which are affective, behavioral, and cognitive attitudes. In terms of the affective attitudes in this study, most of the participants felt using short stories helped them write more effectively. This is also asserted in Oster's study (1989), in which literature imposes the learners to logic and skillful writing that support them in much more effectively writing. Furthermore, reading literary texts, short stories for example, by various authors is bound to be confirm to bring the learners to variety of writing styles; and this would cultivate the learners and motivate them to enhance their own styles of writing. In another research of Stern (2001), he also assists the viewpoint that short stories could be abundant and inspiring sources for writing effectively. However, to support the learners to write more effectively, Pardede (2010) affirms that based on short stories, teachers could design various activities of writing. These activities could help the learners to enhance their writing skills because the short stories are deliberated to be quite comfortable for the learners to follow the story line of the literary works.

Regarding to behavioral attitudes, the result of this study indicated that most learners had higher concentration when reading short stories to upgrade their writing skills. The finding of this study is in alignment with the research from Abrams (1970; p.158) who found out a short story could be read at one sitting of from half an hour to two hours, and that is restrained to single impact, in which the learners could have high concentration. To further discuss, Abrams expresses that since a short story is quite short, and purposes of giving a 'single effect', there is often a plot, a few characters. He also concludes that the objective of utilizing short stories in teaching English is to motivate the learners to use what they have previously comprehended to focus on, and so, it is a student-centered activity. As being instructed by Pardede (2011), the teachers should select short stories which are enough for the learners to conduct within course hours. Concerning about the length of the stories, he also suggests three canonic criteria toward selecting the literary texts: the learners' needs and competency; linguistic and stylistic level of the texts; and the proportion of background knowledge needed for a practical appreciation of the materials.

Concerning cognitive attitudes, the study found that majority of the participants could collect many useful words or word phrases from the short stories for their writing. This finding is consistent with that Ghoorchaei (2016) studying that short stories are greatly significant in developing intermediate EFL learners' lexis. He also confirms, as a literary work, short stories are exciting for the learners since they are relaxing, enhance mental experience and upgrade the learners' lexical range. It is also confirmed in the study of Blachowicz \& Fisher (2004), they reveal that using short stories is an efficient method to cultivate vocabulary in EFL, and learners who read broadly would acquire extensive vocabularies. This is also in line with the finding form the study of Cron (2012) which had the result that short stories facilitate the readers to produce their imagination to capably generate new ideas and foresee the content. This process possibly stimulates the learners to enthusiastically enhance their vocabulary to comprehend the whole story.

\subsubsection{Factors Motivating EFL Learners In Essay Writing Through Short Stories}

Motivation plays a greatly important role in cultivating writing, especially in writing essays by using English short stories in this study. In the domain of intrinsic motivation, the highest mean score belongs to the agreement that the learners had the enjoyment of the storytelling. The finding of this study is in alignment with the research from Elliot (1990, p.197) who confirmed that literature, short stories for instance, could motivate learners and be motivationally joyful if they could comfortably involve in its emotions and feel its artistic characteristics. He also emphasizes the essence of developing student-responses (individuals and groups) and ability in literature. Additionally, another result of the study of Vandrick (1997) reveals that using literary texts would delightfully motivate learners to discover their own feelings and emotions by experiencing the stories. The next result of the research from Pardede (2010) could also support the finding of this study, he expresses that most of the English teachers found short stories exciting to utilize both as materials for self-enjoyment and as the elements of language skills. To build and upgrade the enjoyment of the learners in using short stories, Schulz (1981, p.44) recommends that beside choosing suitable stories to the learners' level of linguistic competence, teachers should also avoid "frustrational reading" which is less than $90 \%$ of accuracy, and 50\% of comprehension. In addition, Akyel and Yalcin (1990) pointed out that the teachers should choose the short stories with different themes, regarding to the learners' preferences, since various themes would provide variety of genres and interests to each of the learners. However, the themes should be aligned with the cultures, or the customs which the learners are associated with. 
In respect of extrinsic motivation, the result of the study explored the high admission of the participants that they could decrease the number of mistakes in writing after using short stories. In the same line with the study of Oster (1989), the finding of which unveils that literature could provide the learners with more chances to write more accurately. It is because, to Oster, short stories could be applied as models for writings of the learners, and this would happen when the writings are related or closely similar to the piece of art or imitating the styles, themes, lexis, grammar structures, and so on. Furthermore, the finding of Lazar (1993) also support the mentioned point, from which he affirms that short stories are highly beneficial via learners on their writing characteristics such as structural, grammatical components. To use short stories as the tools decreasing the mistakes on the learners' writing, he also informs that teachers should carefully design writing tasks which incorporate work on language usable in the short stories. In that process, teachers should provide the learners instruction of the linguistic knowledge, grammar rules, and cultural background information in the short stories, and then offer the learners feedback so that they could recognize their strengths and weaknesses of their writing and discourse capable improvements (Ellis, 2003).

\section{CONCLUSION AND IMPLICATIONS}

The study explored that attitudes of learners consisting of affective, behavioral, and cognitive components had mostly positive influence on the learners' essay writing through using short stories. Additionally, factors motivating EFL learners in essay writing which are intrinsic and extrinsic motivation also had optimistic outcomes. In connection with the learners' attitudes towards using short stories in writing essays, the most major impact was affective attitudes which had the highest mean score among the components while behavioral and cognitive components were considered to be less influential on the learners. Concerning factors motivating EFL learners in essay writing through short stories, the dominant factor belonged to extrinsic motivation whereas intrinsic motivation had less effective influence.

Moreover, the findings of this study expressed some significant points regarding to the learner's attitudes and motivation toward using short stories for their writing essays. First of all, most of the participants agreed that they felt using short stories could help them write more effectively. Also, they had higher concentration when reading short stories to upgrade their wiring skills. They admitted that they could collect many useful words and phrases from the short stories to use for their writing. Last but not least, the participants mostly had the agreement that they had the enjoyment of the storytelling and could decrease the number of mistakes in their writing.

The findings suggest several courses of action for learners, teachers and administrators of the center.First of all, learners should acquire a substantial comprehension of vocabulary, basic grammar, and punctuations, and then take notes and cultivate more from the short stories. In addition, before conducting any essay writing, learners should build an outline in order that they could brainstorm their key ideas logically. To the teachers, should build an attractive learning environment by using familiar short stories which can motivate the learners to writing a good essay. The teachers should provide the leaners instruction of the linguistic knowledge, grammar rules, and cultural background information previously so that the learners could acquire the most useful elements from the short stories and then use them effectively in their writing. In addition, the administrators should take more time to review whether the current curriculum is appropriate to various types of classes and different levels of the learners.

However, the study was limited in several ways. First of all, the size of the sample was not big enough and there was not equality via the number of male and female participants. Secondly, the study was carried out with the research site in my place of work (Vietnam Centre Point) and the level of the participants was mostly intermediate, which could not generalize the whole picture of the topic of the studies. Thirdly, the questions in the questionnaire might not infer all of the aspects which impact learners' essay writing since it could only aim at a small number of the factors. Finally, the items in the questionnaire were adapted mostly from the studies which were generally on short stories, attitudes in writing and motivation in writing, instead of attitudes and motivation towards short stories in essay writing. 


\section{REFERENCES}

[1] Ansarimoghaddam, S., \& Tan, B. H. (2014). Undergraduates' Experiences and Attitudes of Writing in L1 and English. GEMA Online Journal of Language Studies, 14(1). 7-28.

[2] Bruning, R., \& Horn, C. (2000). Developing motivation to write. Educational Psychologist, 35, 25-37.

[3] Ellis, G. \& Brewster, J. (1991). The Storytelling Handbook for Primary Teacher. London: Penguin Group.

[4] Ellis, R. (2003). Task-Based Language Teaching and Learning. Oxford: Oxford University Press.

[5] Graham, S., \& Harris, K. R. (1989). A components analysis of cognitive strategies instruction: Effects on learning disabled students' compositions and self-efficacy. Journal of Educational Psychology, 81, 353361.

[6] Hasan, K. M. and Akhand, M. M. (2010) Approaches to writing in EFL/ESL context: Balancing Product and Process in Writing Class at Tertiary Level: Journal of NELTA. Vol-15, Kathmandu, NELTA.

[7] Hashemian, M., \& Heidari, A. (2013). The relationship between L2 learners' motivation/attitude and success in L2 writing. Procedia-Social and Behavioral Sciences, 70, 476-489.

[8] Jenkins, G. D., \& Taber, T. D. (1977). A Monte Carlo study of factors affecting three indices of composite scale reliability. Journal of Applied Psychology, 62(4), 392-398. https://doi.org/10.1037/00219010.62.4.392

[9] Kotula, A. W., Tivnan, T., \& Aguilar, C. M. (2014). Students' voices: The relationship between attitudes and writing outcomes for fourth and fifth graders. Waltham, MA: Education Development Center.

[10] Krashen, S. D., \& Terrell, T. (1983). The Natural Approach: Language Acquisition in the Classroom. Hayward, CA: Alemany Press.

[11]Lazar, G. (1993). Literature and Language Teaching. Cambridge: CUP.

[12]Leable, V. (2014). The relationship between writing attitude and spelling capabilities in fourth-and fifthgrade students (Master's thesis). University of Wisconsin-River Falls.

[13] McKenna, M. C., \& Kear Ellsworth, R. A. (1995). Children's attitudes toward reading: A national survey. Reading Research Quarterly, 30, 934-956.

[14]Merisuo-Storm, T. (2007). Pupils' attitudes towards foreign-language learning and the development of literacy skills in bilingual education. Teaching and Teacher Education, 23(2), 226-235.

[15] Oppenheim, A. N. (2001). Questionnaire design, interviewing and attitude measurement. London and New York: Continuum.

[16] Slatterly, M., \& Willis, J. (2001). English for Primary Teachers. Oxford: Oxford University Press.

\section{AUTHOR'S BIOGRAPHY}

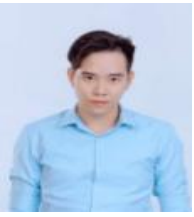

Mr. Giang Nguyen Truong, is currently a master student in Ho Chi Minh University of Technology (HUTECH) - Vietnam, and also a part-time teacher at Ho Chi Minh City Open University. He has had four years in teaching English toward non-English major students. His academic areas of interest are teaching methodology as well as British and American literature.

Mr. Ha Nguyen Dinh Nhu is currently a full-time lecturer of English at Ho Chi Minh City University of Technology (HUTECH) - Vietnam. In addition, he is studying for a Doctorate in Education at Institute of Technical Education (ITE) - Vietnam.

Dr. Tuyen Tran is currently a full-time lecturer at Institute of Technical Education (ITE). He is the professor of Ha Nguyen Dinh Nhu in doing a Doctorate of Education at ITE.

Citation: Giang Nguyen Truong, et.al., "Using Short Stories to Motivate Intermediate EFL Learners in Essay Writing at Vietnam Centre Point" International Journal on Studies in English Language and Literature (IJSELL), vol 8, no. 8, 2020, pp. 25-35. doi: https://doi.org/10.20431/2347-3134.0808004.

Copyright: () 2020 Authors. This is an open-access article distributed under the terms of the Creative Commons Attribution License, which permits unrestricted use, distribution, and reproduction in any medium, provided the original author and source are credited. 